\begin{tabular}{|c|c|}
\hline Title & $\begin{array}{l}\text { Virus removal by an in-line coagulation-ceramic microfiltration process with high-basicity polyaluminum coagulation } \\
\text { pretreatment }\end{array}$ \\
\hline Author(s) & Shirasaki, N.; Matsushita, T.; Matsui, Y.; Urasaki, T.; Kimura, M.; Ohno, K. \\
\hline Citation & $\begin{array}{l}\text { Water Science \& Technology: Water Supply, 14(3), 429-437 } \\
\text { https://doi.org/10.2166/ws.2013.218 }\end{array}$ \\
\hline Issue Date & 2014.06 \\
\hline Doc URL & http:/hdl .handle.net/2115/39426 \\
\hline Rights & $\begin{array}{l}\text { OIWA Publishing 2014. The definitive peer-reviewed and edited version of this article is published in W ater Science \& } \\
\text { Teehnology: Water Supply volume } 14 \text { issue } 3429-4372014 \text { DOI:10.2166/Ws.2013.218 and is available at } \\
\text { www.iwapublishing.com. }\end{array}$ \\
\hline Type & article (author version) \\
\hline File Information & shirasaki_manuscript.pdf \\
\hline
\end{tabular}

Instructions for use 


\title{
Virus removal by an in-line coagulation-ceramic microfiltration process with high-basicity polyaluminum coagulation pretreatment
}

\author{
N. Shirasaki, T. Matsushita, Y. Matsui, T. Urasaki, M. Kimura and K. Ohno
}

\author{
Division of Environmental Engineering, Faculty of Engineering, Hokkaido University, N13W8, Sapporo 060-8628 \\ Japan \\ E-mail: nobutaka@eng.hokudai.ac.jp
}

\begin{abstract}
The ability of in-line coagulation pretreatment with high-basicity polyaluminum chloride (PACl) coagulants to enhance virus removal by ceramic microfiltration was examined by comparing virus removal efficiencies from water pretreated with PACl-2.2 (basicity 2.2) and PACl-2.5 (basicity 2.5) versus alum, a synthetic aluminum chloride $\left(\mathrm{AlCl}_{3}\right)$ solution, and two commercially available PACls, PACl-1.5 and PACl-1.8. The virus removal ratios for $\mathrm{AlCl}_{3}$, alum, PACl-1.5, and PACl1.8 decreased markedly when the $\mathrm{pH}$ of the treated water shifted from 6.8 to 7.8 , but was high at both pHs for PACl-2.2 and PACl-2.5. PACl-2.5 contains $\mathrm{Al}_{13}$ species and possibly $\mathrm{Al}_{30}$ species, and has a high colloid charge density. It removed viruses more efficiently than the other aluminum-based coagulants, not only at neutral $\mathrm{pH}$, but also under weakly alkaline conditions. Moreover, the in-line coagulation-ceramic microfiltration process with PACl-2.5 pretreatment removed not only viruses but also dissolved organic carbon and UV260-absorbing natural organic matter more efficiently and resulted in a lower residual aluminum concentration than did commercially available PACls, especially under weakly alkaline conditions. A combination of coagulation pretreatment with a high-basicity $\mathrm{PACl}$ and ceramic microfiltration can provide effective treatment of drinking water over a broader $\mathrm{pH}$ range than is possible with commercially available aluminum-based coagulants.
\end{abstract}

\section{Keywords}

aluminum hydrolyte species, bacteriophage, ceramic microfiltration, colloid charge density, in-line coagulation

\section{INTRODUCTION}

Low-pressure membrane (LPM) filtration, including microfiltration (MF) and ultrafiltration, is widely used for drinking water treatment because of its ability to produce high-quality water, its small footprint, and its relatively low costs (Huang et al., 2009). To improve the filtration efficiency of LPM, integration of pretreatment with LPM filtration has been widely employed in actual drinking water treatment plants. Pretreatment methods include adsorption, coagulation, and oxidation. Among these methods, coagulation is the most successful pretreatment for controlling membrane fouling (Huang et al., 2009), which reduces membrane permeability and increases the frequency of hydrodynamic or chemical cleaning. In addition, coagulation pretreatment is also useful for improving the quality of treated water. Enhancement of removal of dissolved organic carbon (DOC) and natural organic matter (NOM) can be expected with a combination of precoagulation and membrane filtration (Lee et al., 2000). Moreover, effective removal of waterborne enteric viruses, those having diameters of $20-100 \mathrm{~nm}$, is possible by this hybrid process. For example, Tanneru et al. (2013) have reported that a coagulation-MF process with a coagulant dosage of more than $20 \mathrm{mg}-\mathrm{Al} / \mathrm{L}$ produced 5.5-6.0 log reduction of viruses when the $\mathrm{pH}$ of the treated water was about 6.4, whereas MF alone with a $0.22-\mu \mathrm{m}$-pore-size, hydrophilic polyvinylidene difluoride filter produced only a 0.2-log removal of viruses. Our research group has also reported the effectiveness of the coagulation-MF process: an approximately 6-log reduction of viruses was achieved at around $\mathrm{pH} 6.8$ with a combination of in-line coagulation and a $0.1 \mu \mathrm{m}$ - 
pore-size ceramic membrane filter (Shirasaki et al., 2009). This means that the coagulation-MF process has the potential to effectively mitigate the public health risk posed by virus contamination of drinking water.

Many factors affect the virus removal performance of the coagulation-MF process. Matsushita et al. (2005) have reported the effects of coagulant dosage, coagulation time, and MF membrane pore size on virus removal. They concluded that coagulant dosage strongly affected virus removal compared with two other factors when the $\mathrm{pH}$ was near 7. In addition, Zhu et al. (2005) have investigated the effect of $\mathrm{pH}$ on virus removal and reported a significant reduction of virus removal as the $\mathrm{pH}$ increased from 6.3 to 8.3 when a solution of ferric chloride $\left(\mathrm{FeCl}_{3}\right)$ was used as the coagulant. Adjustment of the $\mathrm{pH}$ during coagulation pretreatment is therefore one of the important steps that must be taken to control virus removal in the coagulation-MF filtration process. However, an increase in the $\mathrm{pH}$ of drinking water sources from neutral to alkaline conditions because of excessive algal growth has been reported throughout the world (Hu et al., 2006; Matsukawa et al., 2006). Under these circumstances, reducing the $\mathrm{pH}$ of the drinking water source with acid or adding more coagulant is sometimes required to improve coagulation efficiency when commercially available aluminum-based coagulants such as polyaluminum chloride (PACl) and alum are used (Hu et al., 2006; Yan et al., 2008). However, both of these methods have some disadvantages, including an increase of the residual aluminum concentration in treated water (Matsukawa et al., 2006) and treatment cost (Yan et al., 2008).

An alternative investigated by some researchers has been the effect of adjusting the aluminum hydrolyte ratio (basicity $=\left[\mathrm{OH}^{-}\right] /\left[\mathrm{Al}^{3+}\right]$ ) in $\mathrm{PACl}$ on DOC removal and residual aluminum concentration during the coagulation process. They have reported that high-basicity PACls (basicity 2.1-2.7) yield higher removal of DOC and lower residual aluminum concentrations than commercially available PACls with basicities of 1.5-1.8, especially under weakly alkaline conditions (Yan et al., 2008; Kimura et al., 2013). Accordingly, effective removal of viruses as well as DOC is possible not only under neutral $\mathrm{pH}$ conditions but also under weakly alkaline conditions when the MF process is combined with a coagulation pretreatment with high-basicity PACl instead of commercially available PACl or alum. However, there is no report about the effectiveness of coagulation pretreatment with high-basicity PACl for virus removal during the coagulation-MF process. Our objective in the present study was to investigate the effects of coagulant type and $\mathrm{PACl}$ basicity on virus removal during the coagulation-MF process by comparing four PACls with different basicity, a synthetic aluminum chloride $\left(\mathrm{AlCl}_{3}\right)$ solution, and commercially available alum.

\section{MATERIALS AND METHODS}

\section{Source water, coagulants, and MF membrane}

On 17 July 2009 and 10 November 2009, river water was sampled from the Toyohira River (Sapporo, Japan), the water quality of which is shown in Table 1 . The coagulants used for the coagulation process were six aluminum-based coagulants, the specifications of which are shown in Table 2. Two commercially available PACls with normal basicities of 1.5 (PACl-1.5) and 1.8 (PACl-1.8) were provided by the Taki Chemical Co., Ltd. (Kakogawa, Japan). For experimental purposes, the same company also supplied high-basicity PACls with basicities of 2.2 (PACl-2.2, presently available commercially) and 2.5. To provide a comparison of coagulation efficiency with PACls, a synthetic $\mathrm{AlCl}_{3}$ solution, which was prepared by dilution of reagent-grade aluminum (III) chloride hexahydrate $\left(\mathrm{AlCl}_{3} \cdot 6 \mathrm{H}_{2} \mathrm{O}\right.$, Wako Pure Chemical Industries, Ltd., Osaka, Japan) dissolved in Milli-Q water (Milli-Q Advantage, Millipore Corp., Billerica, MA, USA), and commercially available alum (Taki Chemical Co., Ltd.), were used in the present study. The distributions of aluminum species in the coagulants were analyzed by a ferron method (Wang et al., 2004) and are shown in Table 2. On the basis of the kinetic differences between the reactions of the aluminum 
species and the ferron reagent (8-hydroxy-7-iodoquinoline-5-sulfonic acid, Wako Pure Chemical Industries), aluminum hydrolyte species were categorized as monomeric species $\left(\mathrm{Al}_{\mathrm{a}}\right)$, fast-reacting polymeric species $\left(\mathrm{Al}_{\mathrm{b}}\right)$, or slow-reacting colloidal species $\left(\mathrm{Al}_{\mathrm{c}}\right)$ (Wang et al., 2004). The details of the ferron method have been described in our previous study (Kimura et al., 2013). A monolithic, modular, ceramic MF membrane (55-channel tubular; nominal pore size $0.1 \mu \mathrm{m}$; effective filtration area $0.043 \mathrm{~m}^{2}$; NGK Insulators, Ltd., Nagoya, Japan) installed in a stainless-steel casing was used for the MF process.

\section{Characterization of coagulants}

\section{Electrospray ionization time-of-flight mass spectrometry}

Electrospray ionization time-of-flight mass spectrometry (ESI-TOF-MS) was used to analyze the aluminum hydrolyte species in the coagulants. Each coagulant was diluted with Milli-Q water to 2 $\mathrm{mg}-\mathrm{Al} / \mathrm{L}$, and the diluted coagulant was introduced into an ESI-TOF-MS (model JMS-T100LP; JEOL Ltd., Tokyo, Japan) at a constant flow rate of $30 \mu \mathrm{L} / \mathrm{min}$ by using a syringe pump. Analysis was conducted in a positive-ion mode at a needle voltage of $2,000 \mathrm{~V}$, an orifice 1 voltage of 10-30 $\mathrm{V}(0-100 \%)$, an orifice 2 voltage of $5 \mathrm{~V}$, a ring lens voltage of $10 \mathrm{~V}$, and a mass range $\mathrm{m} / \mathrm{z}$ of $10-500$.

\section{Colloid titration analysis}

The positive colloid charges of the coagulants were determined by colloid titration with a COM-555 potentiometric titrator (Hiranuma Sangyo Co., Mito, Japan). Each coagulant was diluted with Milli$\mathrm{Q}$ water to 1-2 mg-Al/L (analytical $\mathrm{pH}$ condition was approximately 4-5), and then $150 \mathrm{~mL}$ of diluted coagulant was transferred to a titration vessel. After addition of $0.3 \mathrm{~mL}$ of toluidine blue indicator (Wako Pure Chemical Industries) to the vessel, the solution was titrated by means of a pump with $0.001 \mathrm{~N}$ potassium polyvinyl sulfate (a standard negative colloid, Wako Pure Chemical Industries) at a constant rate of $10 \mathrm{~mL} / \mathrm{min}$. The vessel contents were homogenized with a magnetic stirrer during the titration, and the absorbance at $630 \mathrm{~nm}$ was recorded continuously until there was little change in the absorbance (i.e., subtle change in the color of the indicator from light blue to bluish-purple). The positive colloid charge was determined from the volume of potassium polyvinyl sulfate that corresponded to the half-height of the descending side of the recorded absorbance curve.

\section{Bacteriophage}

F-specific RNA bacteriophage Q $\beta$ (NBRC 20012) was obtained from the NITE Biological Research Center (NBRC, Kisarazu, Japan). The bacteriophage $Q \beta$ is widely used as a surrogate for waterborne enteric viruses in the membrane filtration process (Matsushita et al., 2005; Shirasaki et al., 2009) because of its morphological similarities to hepatitis A viruses and polioviruses, which are important to remove during drinking water treatment. The bacteriophage $\mathrm{Q} \beta$ is the prototype member of the genus Allolevivirus in the virus family Leviviridae. The genome of this bacteriophage contains a single molecule of linear, positive-sense, single-stranded RNA, which is encapsulated in an icosahedral protein capsid with a diameter of 24-26 nm (Fauquet et al., 2005). Bacteriophage was propagated and purified as described in our previous report (Shirasaki et al., 2010) prior to the preparation of a bacteriophage stock solution.

\section{In-line coagulation-ceramic MF experiments}

The river water, placed in a raw water tank, was spiked with $\mathrm{Q} \beta$ at approximately $10^{8} \mathrm{PFU} / \mathrm{mL}$. 
Throughout the experiments, the raw water was mixed constantly with an impeller stirrer. The raw water was fed into the experimental system at a constant flow rate $\left(83.3 \mathrm{~L} /\left(\mathrm{m}^{2} \cdot \mathrm{h}\right)=2.0 \mathrm{~m} / \mathrm{d}\right)$ by a peristaltic pump. To maintain the MF filtrate at $\mathrm{pH} 6.8$ or 7.8, hydrochloric acid or sodium hydroxide was added to the water before it reached the first in-line static mixer [hydraulic retention time (HRT) 1.8 s; 1/4-N40-172-0, Noritake Co., Ltd., Nagoya, Japan]. Because about 1 mg-Al/L of $\mathrm{PACl}$ is usually dosed for the treatment of Toyohira River water (the source water in the present study) in the actual drinking water treatment plant (Moiwa drinking water treatment plant, Sapporo, Japan), coagulant was injected after the first in-line static mixer and before the second in-line static mixer at a constant dose rate $(1.08$ or $2.16 \mathrm{mg}-\mathrm{Al} / \mathrm{L})$. To obtain a coagulation time of $1 \mathrm{~min}$, a combination of the in-line static mixer ( $G$ value $260 \mathrm{~s}^{-1}$, HRT $1.8 \mathrm{~s}$ ) and a subsequent Tygon tube reactor (inside diameter $1.6 \mathrm{~mm}$, total HRT $1 \mathrm{~min}$ ) was used as the second in-line static mixer. After the coagulant had been admixed with the water, the water was fed into the ceramic MF module in dead-end mode. Filtration was performed for $4 \mathrm{~h}$ without any backwashing. Bacteriophage concentrations in the raw water tank $\left(C_{0}\right)$ and in the MF filtrate $\left(C_{\mathrm{f}}\right)$ were measured every hour. In addition, DOC concentrations and UV260-absorbing NOM were quantified with a SIEVERS 900 laboratory TOC analyzer (GE Analytical Instruments, Boulder, CO, USA) and a UV-1700 Pharma spectrophotometer (Shimadzu Corp., Kyoto, Japan), respectively. After adding the nitric acid (1\% (v/v), ultrapure, Kanto Chemical Co., Inc., Tokyo, Japan) into the MF filtrate, the aluminum concentration was analyzed with an HP4500 inductively coupled plasma-mass spectrometer (Yokogawa Analytical Systems Inc., Tokyo, Japan).

\section{Bacteriophage assay}

\section{PFU method}

The infectious bacteriophages were enumerated according to the double-layer method (Adams 1959) by using the bacterial host Escherichia coli (NBRC 13965). Serially diluted raw water or MF filtrate $(1 \mathrm{~mL})$ was poured onto a solid-bottom agar plate followed by $0.3 \mathrm{~mL}$ of host $E$. coli culture mixed with $3 \mathrm{~mL}$ of molten top agar. The plates were incubated for $16-24 \mathrm{~h}$ at $37^{\circ} \mathrm{C}$. To measure the concentrations of infectious bacteriophage in the water samples, we calculated the average plaque counts of triplicate plates prepared from one sample on plates with 30 to $300 \mathrm{PFU}$, which we considered a countable number of plaques, and determined the number of plaque forming units per milliliter.

For quantification of low infectious bacteriophage concentrations (i.e., $<30 \mathrm{PFU} / \mathrm{mL}$ ) in the MF filtrate, $50 \mathrm{~mL}$ of MF filtrate was mixed with $5 \mathrm{~mL}$ of bacterial host $E$. coli culture and $50 \mathrm{~mL}$ molten agar, and the mixture was then poured into 10 plates (without bottom agar). The plates were incubated for $16-24 \mathrm{~h}$ at $37^{\circ} \mathrm{C}$. We calculated the number of plaque forming units per milliliter by dividing the total plaque counts for the 10 plates by the sample volume $(50 \mathrm{~mL})$.

\section{Real-time reverse-transcription polymerase chain reaction method}

The viral RNA of bacteriophages was quantified by the real-time reverse-transcription polymerase chain reaction (RT-PCR) method. This method detects all bacteriophages, regardless of their infectivity and the existence of aggregates. The detailed procedure for the real-time RT-PCR method has been described in our previous study (Shirasaki et al., 2010).

\section{RESULTS AND DISCUSSION}

\section{Effect of coagulant type on bacteriophage removal}


Figure 1a shows the effect of coagulant type on the removal of infectious Q $\beta$, assessed by the PFU method, in the in-line coagulation-ceramic MF process (source water was river water 1). Because the diameter of $\mathrm{Q} \beta$ (approximately $25 \mathrm{~nm}$ ) was smaller than the nominal pore size of the ceramic MF membrane $(0.1 \mu \mathrm{m})$, no removal of infectious $\mathrm{Q} \beta$ was observed in the absence of coagulation pretreatment (data not shown). In contrast, in-line coagulation pretreatment dramatically enhanced the removal ratios $\left(\log \left[C_{0} / C_{\mathrm{f}}\right]\right)$ of infectious $\mathrm{Q} \beta$ compared with ceramic MF alone at around $\mathrm{pH} 6.8$ of treated water. Greater than 6-log removals were achieved by a combination of in-line coagulation pretreatment and ceramic MF filtration, regardless of the type of coagulant, because during the coagulation pretreatment, $\mathrm{Q} \beta$ was effectively incorporated into the aluminum flocs, which were larger than the nominal pore size of the ceramic MF membrane, and the flocs with incorporated Q $\beta$ were removed by ceramic MF filtration.

The infectious $\mathrm{Q} \beta$ removal performances of $\mathrm{AlCl}_{3}$, alum, and PACl-1.5 were markedly decreased when the $\mathrm{pH}$ of the treated water shifted from 6.8 to 7.8. Even when the coagulant dosage was increased from 1.08 to $2.16 \mathrm{mg}-\mathrm{Al} / \mathrm{L},<1-\log$ removals were observed for those coagulants (Figure 1b). In contrast, PACl-2.2 continued to remove viruses with high efficiency ( $>6-\log$ removal of infectious $\mathrm{Q} \beta$ ) even under weakly alkaline $\mathrm{pH}$ conditions (Figure 1a). This result indicates that the type of coagulant affects virus removal performance in the in-line coagulation-ceramic MF process, especially under weakly alkaline $\mathrm{pH}$ conditions, and that a highbasicity PACl (e.g., PACl-2.2) can remove viruses more effectively than the other commercially available aluminum-based coagulants used in the present study.

\section{Effect of PACI basicity on bacteriophage removal}

As described above, PACl-2.2 removed infectious $\mathrm{Q} \beta$ more efficiently than did other aluminumbased coagulants, including PACl-1.5, especially under weakly alkaline $\mathrm{pH}$ conditions. To precisely quantify the effect of PACl basicity on virus removal, we compared the removal of Q $\beta$ by in-line coagulation pretreatment with four PACls with different basicities followed by ceramic MF filtration within the $\mathrm{pH}$ range 6.8-7.8 (Figure 2, source water was river water 2). More than 8-log removals of infectious $\mathrm{Q} \beta$, assessed by the $\mathrm{PFU}$ method, were attained by the in-line coagulation-ceramic MF process with all the PACls when the $\mathrm{pH}$ of the treated water was about 6.8, regardless of their basicity (Figure 2a). In contrast, the removal efficiencies of infectious Q $\beta$ depended on the basicity of the PACls when the $\mathrm{pH}$ of the treated water was about 7.8. The in-line coagulation-ceramic MF process with PACl-1.5 and PACl-1.8 achieved approximately a 1-log removal of infectious $\mathrm{Q} \beta$, but approximately 6-log and $>8$-log removals were achieved with PACl2.2 and PACl-2.5, respectively. A similar trend was observed for removal ratios of total $\mathrm{Q} \beta$, assessed by the RT-PCR method. Although high removal efficiencies of total Q $\beta$, at least 6-log removals, were achieved for all PACls at around $\mathrm{pH}$ 6.8, marked differences in removal ratios were observed among the four PACls when the $\mathrm{pH}$ of the treated water was about 7.8 (Figure $2 \mathrm{~b}$ ). These results suggest that the basicity of PACls affects virus removal performance in the in-line coagulation-ceramic MF process, especially under weakly alkaline conditions.

As shown Figure 2, the in-line coagulation-ceramic MF process with PACl-2.5 effectively removed viruses compared to the performance of the other PACls used in the present study. In addition, this process removed DOC and UV260-absorbing NOM more efficiently and resulted in a lower residual aluminum concentration than did the processes with PACl-1.5, PACl-1.8, and PACl2.2, especially under weakly alkaline conditions (whereas approximately $20-30 \%$ and $40-50 \%$ removals for DOC and UV260-absorbing NOM, respectively, and $0.08-0.15 \mathrm{mg}-\mathrm{Al} / \mathrm{L}$ residual aluminum concentrations were observed for PACl-1.5, PACl-1.8, and PACl-2.2 at a pH of about 7.8, approximately 50\% and 70\% removals for DOC and UV260-absorbing NOM, respectively, and $<0.01 \mathrm{mg}-\mathrm{Al} / \mathrm{L}$ residual aluminum concentrations were attained for PACl-2.5). Accordingly, the 
combination of coagulation pretreatment with high-basicity $\mathrm{PACl}$ and ceramic MF is effective in treating drinking water, including virus removal, over a broader $\mathrm{pH}$ range compared to commercially available aluminum-based coagulants.

The $\mathrm{Q} \beta$ removal ratios determined by the PFU and RT-PCR methods differed markedly, depending on the coagulation conditions. The infectious $Q \beta$ removal ratios (Figure 2a) were larger than the total $\mathrm{Q} \beta$ removal ratios (Figure $2 \mathrm{~b}$ ). Because our previous study demonstrated that $\mathrm{Q} \beta$ loses its infectivity after being mixed with aluminum hydrolyte species during coagulation with PACl-1.5 (Matsushita et al., 2011), the virucidal activity of the PACls contributed to the removal efficiency of infectious $\mathrm{Q} \beta$ during the in-line coagulation-ceramic MF process.

\section{Characterization of coagulants}

To elucidate why PACl-2.5, which has a higher basicity, was more effective in removing viruses, we used ESI-TOF-MS to analyze the aluminum hydrolyte speciation in PACl-2.5. In the ESI-TOFMS spectra of all the coagulants (Figure 3), we found the most intensive peak at $\mathrm{m} / \mathrm{z}$ 97, which is assigned to the monomeric aluminum species $\left[\mathrm{Al}(\mathrm{OH})_{2}\left(\mathrm{H}_{2} \mathrm{O}\right)_{2}\right]^{+}$(Urabe et al., 2007). In addition, fragment ions of tridecameric species-i.e., $\mathrm{Al}_{13}$ species such as $\left[\left(\mathrm{Al}_{13} \mathrm{O}_{4}(\mathrm{OH})_{24}\left(\mathrm{H}_{2} \mathrm{O}\right)_{12}\right)\right]^{7+}$ with peaks at $\mathrm{m} / \mathrm{z} 303\left[\mathrm{Al}_{13} \mathrm{O}_{4}(\mathrm{OH})_{28}\left(\mathrm{H}_{2} \mathrm{O}\right)\right]^{3+}$ and $454\left[\mathrm{Al}_{13} \mathrm{O}_{4}(\mathrm{OH})_{29}\right]^{2+}$ (Stewart et al., 2009)-were also observed for PACl-2.2 (the relative intensities of these two peaks were $0.7-0.9 \%$ ) and PACl2.5. In contrast, no peak for $\mathrm{Al}_{13}$ species was confirmed in the spectra of $\mathrm{AlCl}_{3}$, alum, $\mathrm{PACl}-1.5$, and PACl-1.8. Moreover, other strong peaks of $\mathrm{Al}_{13}$ species at $m / z 297\left[\mathrm{Al}_{13} \mathrm{O}_{4}(\mathrm{OH})_{28}\right]^{3+}, 309,315$, 321, 327, and $333\left[\mathrm{Al}_{13} \mathrm{O}_{4}(\mathrm{OH})_{28}\left(\mathrm{H}_{2} \mathrm{O}\right)_{2-6}\right]^{3+}$ (Stewart et al., 2009) were observed in the spectrum of PACl-2.5. These results suggest that high-basicity PACls such as PACl-2.2 and PACl-2.5 contain $\mathrm{Al}_{13}$ species, but these species are not present in $\mathrm{AlCl}_{3}$, alum, PACl-1.5, and PACl-1.8.

Some researchers have demonstrated that the content of $\mathrm{Al}_{13}$ species in a coagulant is approximately equal to that of $\mathrm{Al}_{\mathrm{b}}$ species categorized by the ferron method (Chen et al., 2006). In the present study, whereas strong peaks related to $\mathrm{Al}_{13}$ species were observed for PACl-2.5, the content of $\mathrm{Al}_{\mathrm{b}}$ in PACl-2.5 was very similar to those in other aluminum-based coagulants used in the present study (Table 2). In contrast, the content of $\mathrm{Al}_{\mathrm{C}}$ varied as a function of the coagulant type and was highest in PACl-2.5 (Table 2). Because the $\mathrm{Al}_{30}$ species $\left[\left(\mathrm{Al}_{30} \mathrm{O}_{4}(\mathrm{OH})_{56}\left(\mathrm{H}_{2} \mathrm{O}\right)_{24}\right)\right]^{18+}$ does not react with ferron reagents within $120 \mathrm{~min}$, it is categorized as $\mathrm{Al}_{\mathrm{C}}$ by the ferron method (Chen et al., 2007). In addition, the $\mathrm{Al}_{30}$ species is known to consist of two $\mathrm{Al}_{13}$ species connected by four monomeric aluminum species (Chen et al., 2007), the implication being that the peaks of monomeric aluminum species and fragment ions of $\mathrm{Al}_{13}$ species will also be observed when the $\mathrm{Al}_{30}$ species in a coagulant is decomposed by fragmentation in the ESI-TOF-MS analysis. Actually, these peaks were clearly confirmed in the ESI-TOF-MS spectrum of PACl-2.5, as shown in Figure 3. Therefore, PACl-2.5 possibly contained not only $\mathrm{Al}_{13}$ species but also $\mathrm{Al}_{30}$ species.

The positive colloid charges of the coagulants were also determined by using a colloid titration technique (Figure 4). The colloid charge densities of the $\mathrm{AlCl}_{3}$ and alum were very small and almost constant, regardless of the aluminum concentration. In contrast, the colloid charge densities of the PACls increased with increasing concentrations of aluminum. In addition, the colloid charge density of PACl-2.5 was the highest among the aluminum-based coagulants used in the present study. Because $\mathrm{Al}_{13}$ species and $\mathrm{Al}_{30}$ species are known to be effective coagulants because of their strong charge neutralization capability and high structural stability (Chen et al., 2006; Zhang et al., 2008), the presence of $\mathrm{Al}_{13}$ species, $\mathrm{Al}_{30}$ species, or both in $\mathrm{PACl}-2.5$ is possibly associated with the large amount of positive colloid charge. In addition, the absence of sulfate in PACl-2.5 probably also contributed to its high colloid charge density compared with that of other sulfated PACls such as PACl-1.5, PACl-1.8, and PACl-2.2, because the presence of sulfate during the coagulation process reduces the charge neutralization capability of coagulants (Wang et al., 2002). These characteristics of PACl-2.5 account for its high capability to neutralize the negative charges on 
viruses during coagulation pretreatment. Actually, the in-line coagulation-ceramic MF process with PACl-2.5 could effectively remove viruses not only under neutral $\mathrm{pH}$ conditions but also under weakly alkaline conditions, as described above.

We have shown through this study that coagulation pretreatment with PACl-2.5 followed by ceramic MF has a variety of advantages, including effective removal of viruses, DOC, and UV260absorbing NOM, and the process results in very low residual aluminum concentrations compared with other aluminum-based coagulants, even under weakly alkaline conditions. To elucidate whether the in-line coagulation-ceramic MF process with high-basicity PACl is actually useful for drinking water treatment, further investigations using a wide variety of water sources are needed, because the concentration of viruses in the treated water may be affected by the characteristics of the source water.

\section{CONCLUSIONS}

1. The basicity of PACls affects the virus removal performance of the in-line coagulation-ceramic MF process. The high-basicity PACls, PACl-2.2 and PACl-2.5, could effectively remove viruses not only under neutral $\mathrm{pH}$ conditions but also under weakly alkaline conditions.

2. Among the various aluminum-based coagulants used in the present study, PACl-2.5, which has a high $\mathrm{Al}_{c}$ content (including $\mathrm{Al}_{13}$ species and possibly $\mathrm{Al}_{30}$ species) and a high colloid charge density, removed viruses more efficiently (>8-log for infectious viruses; >6-log for total viruses) than the other aluminum-based coagulants in the $\mathrm{pH}$ range 6.8 to 7.8 .

3. The in-line coagulation-ceramic MF process with PACl-2.5 removed not only viruses but also DOC and UV260-absorbing NOM more efficiently and resulted in a lower residual aluminum concentration than did commercially available PACls, especially under weakly alkaline conditions.

\section{ACKNOWLEDGMENTS}

This research was supported in part by a Grant-in-Aid for Young Scientists A (no. 25709044, 2013), a Grant-in-Aid for Scientific Research S (no. 24226012, 2012) and B (no. 24360211, 2012) from the Japan Society for the Promotion of Science (JSPS), a Grant-in-Aid (2013) from the Ministry of Health, Labor and Welfare of Japan, and the Kurita Water and Environment Foundation (no. 23050, 2011).

\section{REFERENCES}

Adams, M. H. (1959). Bacteriophages. Interscience Publishers, New York, NY, USA, pp. 450-454. Chen, Z., Fan, B., Peng, X., Zhang, Z., Fan, J. and Luan, Z. (2006). Evaluation of $\mathrm{Al}_{30}$ polynuclear species in polyaluminum solutions as coagulant for water treatment. Chemosphere 64(6), 912918.

Chen, Z., Luan, Z., Fan, J., Zhang, Z., Peng, X. and Fan, B. (2007). Effect of thermal treatment on the formation and transformation of Keggin $\mathrm{Al}_{13}$ and $\mathrm{Al}_{30}$ species in hydrolytic polymeric aluminum solutions. Colloid Surface A 292(2-3), 110-118.

Fauquet, C. M., Mayo, M. A., Maniloff, J., Desselberger, U. and Ball, L. A., Ed. (2005). Virus Taxonomy: Eighth report of the International Committee on Taxonomy of Viruses. Elsevier Academic Press, London, UK, pp. 741-750.

Hu, C. Z., Liu, H. J., Qu, J. H., Wang, D. S. and Ru, J. (2006). Coagulation behavior of aluminum salts in eutrophic water: Significance of $\mathrm{Al}_{13}$ species and $\mathrm{pH}$ control. Environ. Sci. Technol. 
40(1), 325-331.

Huang, H., Schwab, K. and Jacangelo, J. G. (2009). Pretreatment for low pressure membranes in water treatment: A review. Environ. Sci. Technol. 43(9), 3011-3019.

Kimura, M., Matsui, Y., Kondo, K., Ishikawa, T., Matsushita, T. and Shirasaki, N. (2013). Minimizing residual aluminum concentration in treated water by tailoring properties of polyaluminum coagulants. Water Res. 47(6), 2075-2084.

Lee, J. D., Lee, S. H., Jo, M. H., Park, P. K., Lee, C. H. and Kwak, J. W. (2000). Effect of coagulation conditions on membrane filtration characteristics in coagulation-microfiltration process for water treatment. Environ. Sci. Technol. 34(17), 3780-3788.

Matsukawa, S., Itoho, S., Habuthu, S. and Aizawa, T. (2006). An approach to residual aluminium control at Nisiya purification plant, Water Works Bureau, Yokohama. Water Sci. Technol. Water Supply 6(4), 67-74.

Matsushita, T., Matsui, Y., Shirasaki, N. and Kato, Y. (2005). Effect of membrane pore size, coagulation time, and coagulant dose on virus removal by a coagulation-ceramic microfiltration hybrid system. Desalination 178(1-3), 21-26.

Matsushita, T., Shirasaki, N., Matsui, Y. and Ohno, K. (2011). Virus inactivation during coagulation with aluminum coagulants. Chemosphere 85(4), 571-576.

Shirasaki, N., Matsushita, T., Matsui, Y., Kobuke, M. and Ohno, K. (2009). Comparison of removal performance of two surrogates for pathogenic waterborne viruses, bacteriophage Q $\beta$ and MS2, in a coagulation-ceramic microfiltration system. J. Membrane Sci. 326(2), 564-571.

Shirasaki, N., Matsushita, T., Matsui, Y., Oshiba, A. and Ohno, K. (2010). Estimation of norovirus removal performance in a coagulation-rapid sand filtration process by using recombinant norovirus VLPs. Water Res. 44(5), 1307-1316.

Stewart, T. A., Trudell, D. E., Alam, T. M., Ohlin, C. A., Lawler, C., Casey, W. H., Jett, S. and Nyman, M. (2009). Enhanced water purification: A single atom makes a difference. Environ. Sci. Technol. 43(14), 5416-5422.

Tanneru, C. T., Rimer, J. D. and Chellam, S. (2013). Sweep flocculation and adsorption of viruses on aluminum flocs during electrochemical treatment prior to surface water microfiltration. Environ. Sci. Technol. 47(9), 4612-4618.

Urabe, T., Tanaka, M., Kumakura, S. and Tsugoshi, T. (2007). Study on chemical speciation in aluminum chloride solution by ESI-Q-MS. J. Mass. Spectrom. 42(5), 591-597.

Wang, D., Tang, H. and Gregory, J. (2002). Relative importance of charge neutralization and precipitation on coagulation of kaolin with PACl: effect of sulfate ion. Environ. Sci. Technol. 36(8), 1815-1820.

Wang, D., Sun, W., Xu, Y., Tang, H. and Gregory, J. (2004). Speciation stability of inorganic polymer flocculant-PACl. Colloid Surface A 243(1-3), 1-10.

Yan, M. Q., Wang, D. S., Qu, J. H., Ni, J. R. and Chow, C. W. K. (2008). Enhanced coagulation for high alkalinity and micro-polluted water: The third way through coagulant optimization. Water Res. 42(8-9), 2278-2286.

Zhang, P., Wu, Z., Zhang, G., Zeng, G., Zhang, H., Li, J., Song, X. and Dong, J. (2008).

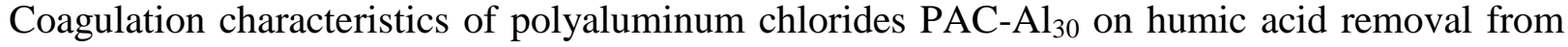
water. Sep. Purif. Technol. 63(3), 642-647.

Zhu, B., Clifford, D. A. and Chellam, S. (2005). Virus removal by iron coagulation-microfiltration. Water Res. 39(20), 5153-5161. 
Table 1 Water quality of the Toyohira River

\begin{tabular}{ccc}
\hline & River water 1 & River water 2 \\
\hline Sampling date & 17-Jul-09 & 10-Nov-09 \\
pH & 7.5 & 7.7 \\
Turbidity (NTU) & 2.0 & 0.8 \\
DOC (mg/L) & 0.9 & 0.8 \\
UV260 (cm $\left.{ }^{-1}\right)$ & 0.031 & 0.027 \\
Alkalinity $\left({\left.\mathrm{mg}-\mathrm{CaCO}_{3} / \mathrm{L}\right)}\right.$ & 14.5 & 22.2 \\
\hline
\end{tabular}


Table 2 Specifications of aluminum-based coagulants used in the present study

\begin{tabular}{|c|c|c|c|c|c|c|c|}
\hline \multirow{2}{*}{ Coagulants } & \multirow{2}{*}{ Basicity } & \multirow{2}{*}{ Aluminum concentration } & \multirow{2}{*}{ Sulfate concentration } & \multirow{2}{*}{ Relative density at $20^{\circ} \mathrm{C}$} & \multicolumn{3}{|c|}{ Aluminum species distribution } \\
\hline & & & & & $\mathrm{Al}_{\mathrm{a}}(\%)$ & $\mathrm{Al}_{\mathrm{b}}(\%)$ & $\mathrm{Al}_{\mathrm{c}}(\%)$ \\
\hline $\mathrm{AlCl}_{3}$ & 0.0 & $2.7 \mathrm{~g}-\mathrm{Al} / \mathrm{L}$ & $0.0 \mathrm{~g} / \mathrm{L}$ & 1.0 & 75.8 & 4.6 & 19.6 \\
\hline Alum & 0.0 & $8 \%(\mathrm{w} / \mathrm{w})$ as $\mathrm{Al}_{2} \mathrm{O}_{3}$ & $23 \%(w / w)$ & 1.3 & 73.3 & 9.4 & 17.3 \\
\hline PACl-1.5 & 1.5 & $10 \%(\mathrm{w} / \mathrm{w})$ as $\mathrm{Al}_{2} \mathrm{O}_{3}$ & $3 \%(w / w)$ & 1.2 & 46.2 & 15.5 & 38.3 \\
\hline PACl-1.8 & 1.8 & $10 \%(\mathrm{w} / \mathrm{w})$ as $\mathrm{Al}_{2} \mathrm{O}_{3}$ & $3 \%(w / w)$ & 1.2 & 42.2 & 11.6 & 46.3 \\
\hline PACl-2.2 & 2.2 & $10 \%(\mathrm{w} / \mathrm{w})$ as $\mathrm{Al}_{2} \mathrm{O}_{3}$ & $3 \%(w / w)$ & 1.2 & 36.4 & 6.3 & 57.3 \\
\hline PACl-2.5 & 2.5 & $23 \%(\mathrm{w} / \mathrm{w})$ as $\mathrm{Al}_{2} \mathrm{O}_{3}$ & $0 \%(w / w)$ & 1.3 & 24.6 & 3.8 & 71.6 \\
\hline
\end{tabular}



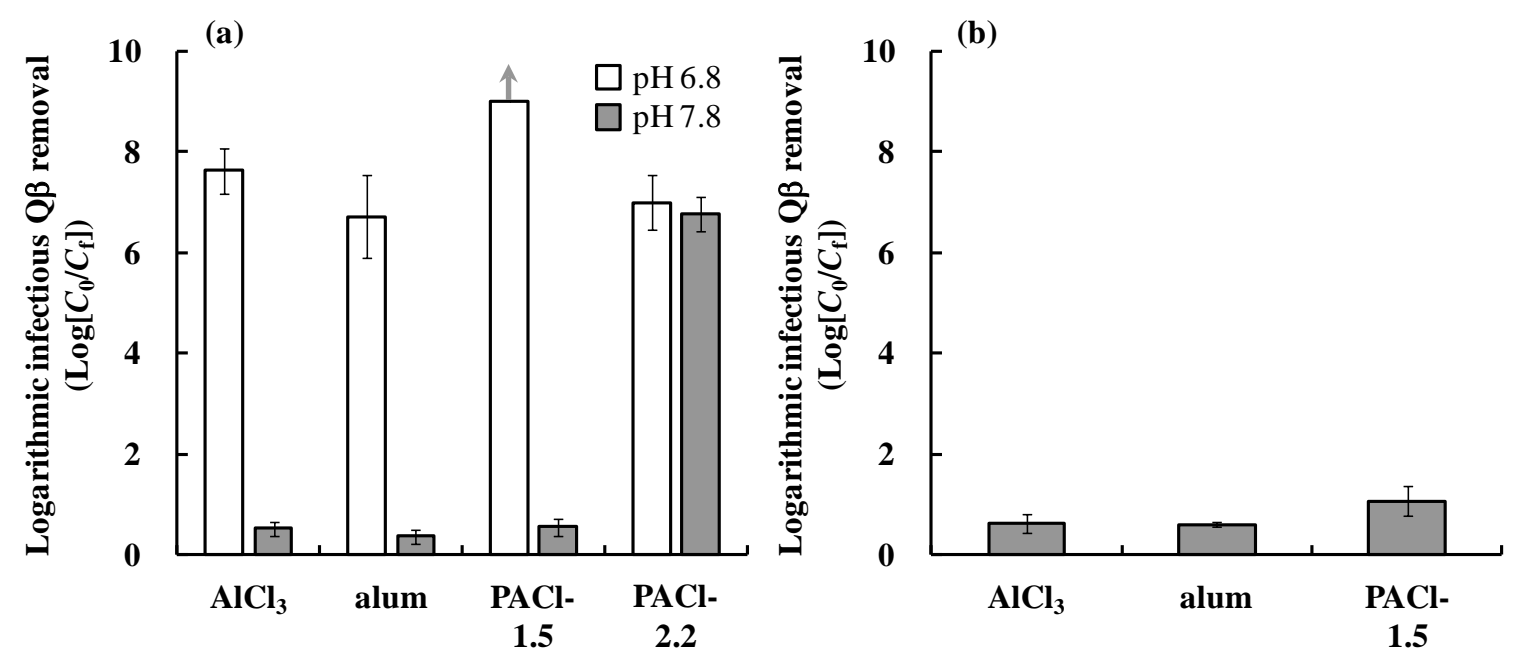

Figure 1 Effect of coagulant type on removal of infectious $Q \beta$ by the in-line coagulation-ceramic MF process as evaluated by the PFU method. Source water was river water 1 . Coagulant dosage was 1.08 (a) or 2.16 (b) mg-Al/L. Values are filtration time-averaged removals, and the error bars indicate standard deviations. The absence of a bar indicates that the $\mathrm{Q} \beta$ concentrations were below the quantification limit in the treated water. 

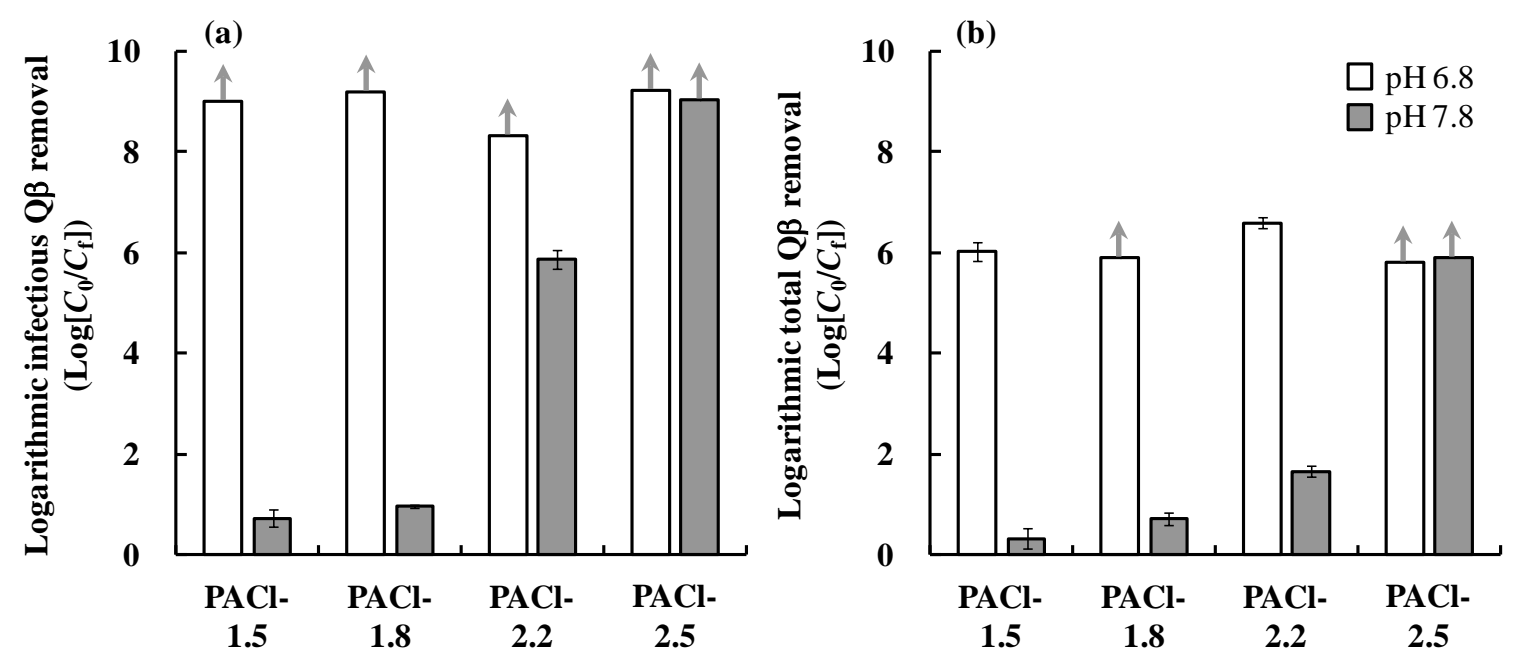

Figure 2 Effect of PACl basicity on infectious Q $\beta$ removal as evaluated by the PFU method (a) and on total Q $\beta$ removal as evaluated by the RT-PCR method (b) by the in-line coagulation-ceramic MF process. Source water was river water 2 . Coagulant dosage was $1.08 \mathrm{mg}-\mathrm{Al} / \mathrm{L}$. Values are filtration time-averaged removals, and the error bars indicate standard deviations. The absence of a bar indicates that the $\mathrm{Q} \beta$ concentrations were below the quantification limit in the treated water. 

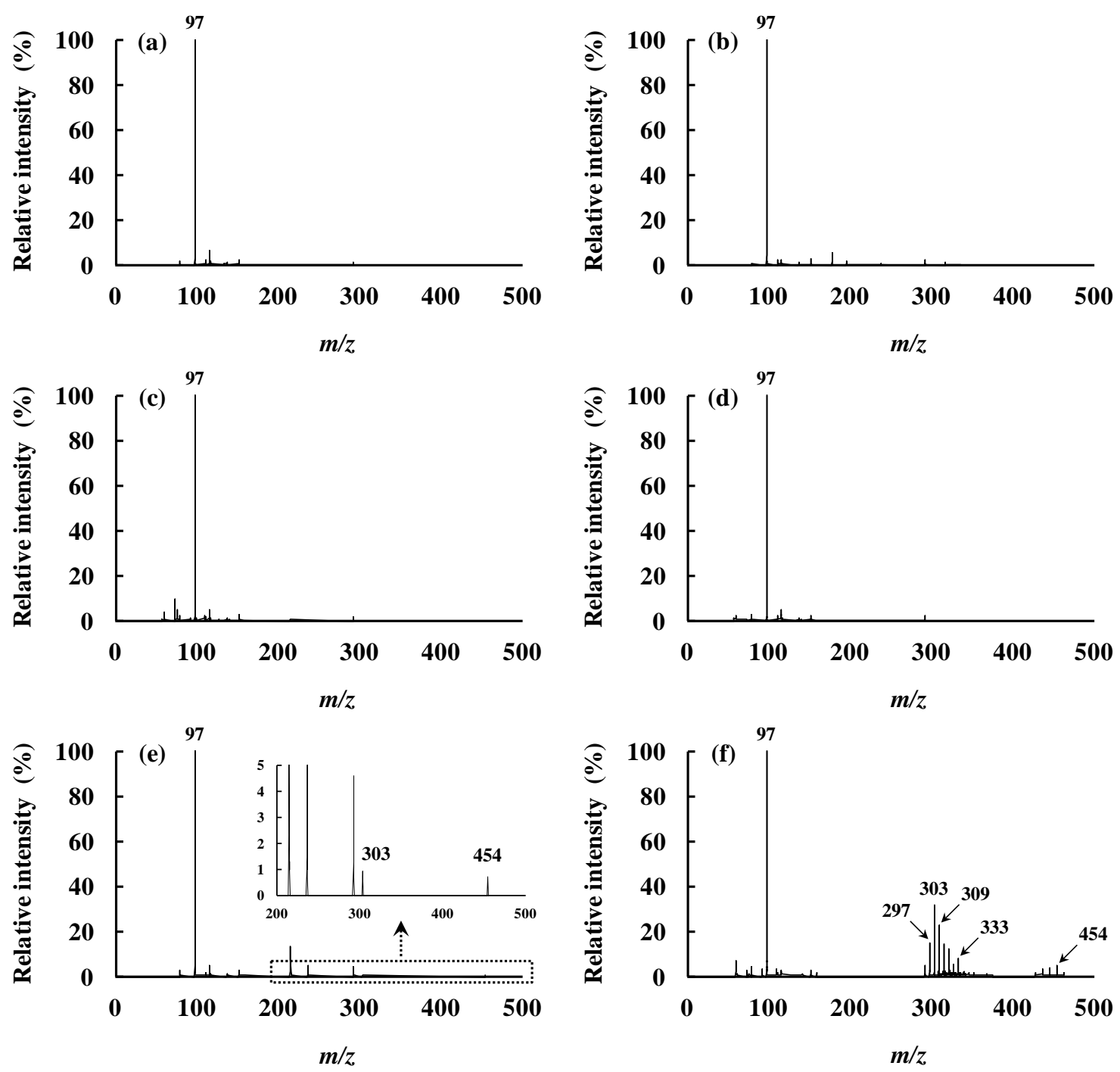

Figure 3 ESI-TOF-MS spectra of coagulants: $\mathrm{AlCl}_{3}$ (a), alum (b), PACl-1.5 (c), PACl-1.8 (d), PACl-2.2 (e), and PACl-2.5 (f). 


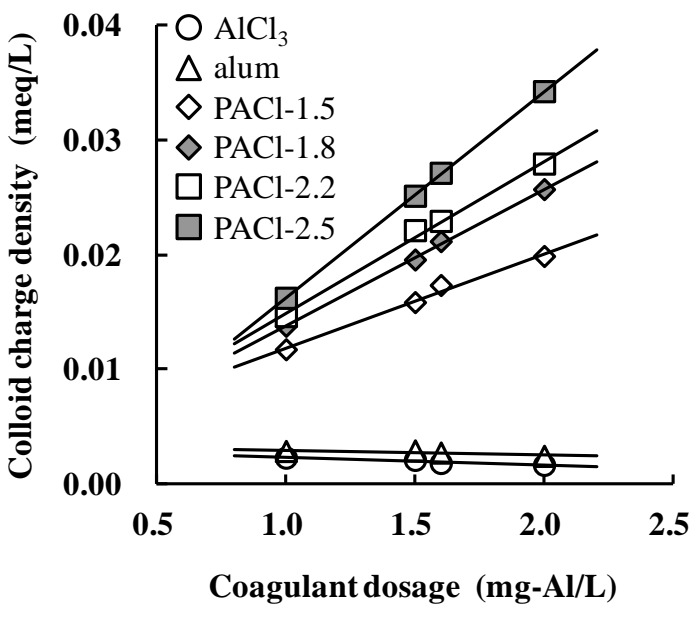

Figure 4 Colloid charges densities of the coagulants as evaluated by the colloid titration technique. 